\title{
Chapter 10 \\ Creating an Evidence Base for Social Work, Group Work, and Psychodrama
}

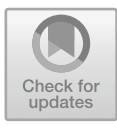

\begin{abstract}
This chapter is devoted to outlining the research literature of psychodrama and group therapy. Evidence-based practice trends and their impact on practice in the field of social work are described. Psychodrama is also framed within the research bases of the humanistic-experiential psychotherapies, creative arts therapies, and body- and movement-oriented therapies. While the quality and quantity of research available on the effectiveness of psychodrama are limited, current findings support its use to as a treatment for various mental health conditions. Shortcomings and critiques of research in psychodrama are included while indicating a need for higher quality psychodrama research studies. The research history of psychodrama's founder, Jacob Moreno, is also described to provide insight on psychodrama's historical relationship to research.
\end{abstract}

Keywords Evidence-based social work $\cdot$ Psychodrama research $\cdot$ Group psychotherapy research $\cdot$ Experiential psychotherapy $\cdot$ Effectiveness

\subsection{Social Work and Evidence-Based Practice}

The social work's struggle to establish itself as a professionalized field traces back to the beginnings of social work. Okpych and Yu (2014) highlight three major shifts in social work's practice paradigm - first a paradigm based on morality and charity, then a paradigm based on tradition and authority of the psychoanalytic approach, and now a paradigm grounded in empirical research.

This shift toward empirical clinical practice (ECP) seems to have begun in the late 1960s and shifted the paradigm from practicing based on appeal, tradition, or consensus to a clinical practice rooted in evidence and effectiveness (Okpych \& Yu, 2014; Witkin, 2017). This new ECP paradigm challenged social workers to routinely assess and evaluate the effectiveness of their work while also urging social work researchers to systematically evaluate the effectiveness of various approaches on a large scale. In part, the ECP movement was stimulated by a series of research studies concluding that certain social work approaches were not effective or even

S. Giacomucci, Social Work, Sociometry, and Psychodrama, Psychodrama in Counselling, 
causing harm (Briar, 1967; Fischer, 1973, 1978; Okpych \& Yu, 2014). Simultaneously, computer technology had advanced to the point of making complex data analysis and research publication significantly more effective (Bronson \& Blythe, 1987; Glass, 1976; Glisson, 1982). The influence of the ECP movement in social work at that time is evidenced by the 1984 Council on Social Work Education (CSWE) change in curriculum standards requiring social workers to "evaluate their own practice systematically" (1988, 127). Still, in 1991, the Task Force on Social Work Research exclaimed that the social work field was too detached from research (Okpych \& Yu, 2014).

Empirical clinical practice created controversy within the social work field and was criticized by some (Witkin, 2017). Witkin (1991, 2017) argued that the ECP model placed too much focus on objectivity and disregarded the social, cultural, and political influences in clinical social work-in effect, ignoring the relational and social aspects of person-in-environment. Okpych and Yu further highlight this conflict in the following passage:

In particular, critics drew attention to logical positivist assumptions that undergirded ECP: that social phenomena were absolute entities and that researchers could impartially and objectively observe these phenomena through preconstructed, standardized measurement. Alternatively, some argued that social phenomena emerge in structures of power, systems of language, and webs of meaning, and that methodologies should be adopted that explore rather than delimit phenomena, reveal rather than control extraneous factors, and acknowledge rather than disavow the researcher's interpretive frame. (Okpych and Yu 2014, p. 19)

The ECP movement in social work had begun to lose traction in the 1990s, until it was revitalized by the evidence-based medicine (EBM) movement which had engulfed the fields of medicine and psychology (2017). As systematic reviews and meta-analyses began to emerge in exponential numbers, policy makers, government agencies, nonprofit funders, and insurance companies began requiring evidencebased practice (EBP) implementation for funded programs. Multiple registries and organizations emerged to systematically review the evidence base of different programs and interventions including the Cochrane Review, the Campbell Collaborative, the Substance Abuse and Mental Health Service Administration's Registry of Evidence-Based Programs and Practices, and the list of EBPs evaluated by Division 12 of the American Psychological Association.

The contemporary EBP model outlined by Haynes et al. (2002) includes the integration and intersection of four parts:

1. The clinical presentation and circumstances of the client

2. The literature base of related research

3. The values and preferences of the client

4. The skill, expertise, and area of competence of the clinician.

Evidence-based practice has been defined as "a process that incorporates current research evidence with clinical expertise and client expectations and values" (Sackett et al., 1996, as cited by Wike et al., 2014, p. 161). The movement toward EBP is fueled by the virtuous goal of preventing harm and providing the absolute best practices for clients. In some ways, social work's adoption of EBP was an attempt to 
move the profession toward a scientific base for clinical practice and away from the intuition-based clinical practice that much of the field continues to operate from.

When it comes to different types of evidence or research, EBP subscribes to a hierarchy of evidence that places low value in qualitative studies and high value in controlled, randomized quantitative research and meta-analysis. McNeece and Thyer (2004) outline this hierarchy of evidence below:

1. Systematic reviews/meta-analyses

2. Randomized controlled trials

3. Quasi-experimental studies

4. Case-control and cohort studies

5. Pre-experimental group studies

6. Surveys

7. Qualitative studies.

Though not highly regarded in the hierarchy of evidence, some social work research experts have promoted qualitative methods as most complimentary to the social work practice values because of their overlap in making sense of client narratives, conducting qualitative interviews, understanding social phenomenon, exploring complexities of direct experience, meeting the client where they are at, and attention to person-in-environment (Fortune et al., 2013; Gray et al., 2009; Gilgun, 1994; Padgett, 1998; Shaw \& Holland, 2014). Cheetham (1992) suggests that studying outcomes and efficacy in social work has little value unless we also use qualitative methods to understand the process of change.

\subsection{Limitations and Critiques of Evidence-Based Practice}

By the mid-2000s, the term evidence-based practice had become increasingly popular and was frequently used without attention to its precise meaning or the quality and rigor of evidence that a practice was effective (Shlonsky \& Gibbs, 2004). Treatment approaches that made their way onto one of the evidence-based practice registries based on research for treating one specific mental health disorder are often misleadingly promoted as an evidence-based practice for any condition. Critics of EBP have argued that it is too medicalized and attempts to separate the individual from their biopsychosocial reality while prescribing rigid interventions that do not honor client diversity, client preferences, the therapeutic relationship, or the practice wisdom of the social worker (Adams et al., 2009; Berger, 2010; Borntrager et al., 2009; Drisko \& Grady, 2015; Goldstein et al., 2009; Magill, 2006; Manuel et al., 2009; Witkin, 2017). Others criticize the use of treatment manuals, citing the growing literature base supporting the effectiveness of the therapeutic relationship (Norcross \& Lampbert, 2011). Wike et al. (2014) underscore that while EBP has become popular in the field of social work, "effective approaches for translating research evidence into social work practice remain elusive" (p. 161). Witkin (2017) argues that EBP focuses more on cognitive knowing than on the practical doing of clinical work. Many social workers 
report that they do not fully understand the statistics and research methods in the literature and cannot differentiate between useful and misleading results (BledsoeMansori et al., 2013; Wike et al., 2014). Researchers organize information based on units of measurement, while therapists organize information into a meaningful psychosocial narrative (Witkin, 2017).

While the EBP movement has its limitations and faults, it is also important to acknowledge the ethical responsibilities of social workers to utilize approaches that are effective and do not cause harm to clients. There is no disagreement with this ethical principle and the overall goal of EBP. Many argue that when it comes to generalizing best practices of creating evidence, evaluating evidence, prioritizing different types of evidence, generalizing research, and integrating knowledge of best practices from controlled research environments into real-world clinical practice, important distinctions are not taking into consideration which suggest that EBPs lead to the disintegration of core social work values in clinical practice, namely the importance of relationships (Goldstein et al., 2009; Okpych \& Yu, 2014; Witkin, 2017). Shulman (2016) highlights how EBP used in the social work field is often created by nonsocial workers and does not reflect the core values of the social work profession. EBP has the potential of reenacting and upholding systems of oppression and the imbalance of power dynamics within clinical social work (Witkin, 2017). Even the National Institutes of Health have acknowledged the problems with using EBPs in social work agencies (Shulman, 2016). Reamer (1992) eloquently states that:

Empiricism can be taken too far.... While [it] can certainly inform and guide intervention, we must be sure that it does not strip interventions of its essential ingredients - a keen sense of humanity, compassion, and justice and the ability to engage and work with people.... Truly enlightened practice integrates the systematic method of empiricism with the valuable knowledge that social workers have once regarded as .... Practice wisdom and professional intuition. (p. 258, as cited in Goldstein et al., 2009, p. 17)

In the search for best practices for our clients, we must not forget to continue to meet clients where they are. A rigid adherence to EBP seems to negate a clientcentered approach in favor of a therapist-centered or, more precisely, an interventioncentered approach.

While the EBP approach has become central to the social work field, some advocate the Common Factors Perspective as an alternative narrative to evaluating efficacy research (Witkin, 2017). Various research studies have demonstrated that the specifics of treatment interventions are less important than certain common factors when it comes to their efficacy in psychotherapy-especially the therapeutic relationship (Laska et al., 2014; Messer \& Wampold, 2002; Wampold, 2005; Witkin, 2017). These common factors are outlined by Laska et al. (2014) to include:

1. The therapeutic relationship between client and therapist

2. A safe and healing setting within which sessions take place

3. A therapist offering a culturally appropriate psychological understanding of suffering

4. An adaptive framework for change that the client understands and believes 
5. A process/ritual enacted by therapist and client that provides something useful.

These common factors have been simplified by Wampold (2012) into a humanistic framework focused on "(a) making sense of the world, (b) influencing through social means, and (c) connectedness, expectation, and mastery" (p. 445). The common factor approach seems to orient itself on the overall process of psychotherapy as evidence-based practice rather than emphasizing specific manualized content in psychotherapy. Witkin (2017) suggests that this focus on process of common factors offers a fitting alternative to EBP for the social work profession.

One of the most respected group therapists of the century, Irving Yalom, reminds us that when it comes to EBP, non-validated therapies are not invalidated therapies (2002). He writes that EBP and the nature of controlled scientific research favor interventions that are brief, replicable, and manualized — which gives cognitive behavioral therapy (CBT) and other cognitive or behavioral approaches an advantage. Other approaches that orient themselves on genuine therapeutic relationship, the here-andnow experience, and spontaneity are inherently disadvantaged. Yalom finishes his chapter on empirically validated therapy (EVT) by proposing the following "mischievous point." "I have a strong hunch (substantiated only anecdotally) that EVT practitioners requiring personal psychotherapeutic help do not seek brief cognitivebehavioral therapy but instead turn to highly trained, experienced, dynamic, manualless therapists" (Yalom, 2002, p. 224). Perhaps clinicians early in their career may be more inclined to rely on manualized treatments, while seasoned therapists may be less likely to.

\subsection{Group Psychotherapy Research}

Most of the evidence-based practice movement seems to be focused on individual psychotherapy rather than group therapy. Individual therapy outcomes may not be generalizable to group work settings as "there are in fact different factors reflecting different processes that occur in group and individual treatment" (Holmes \& Kivlighan, 2000, p. 482). Nevertheless, a wealth of research on the efficacy of group psychotherapy has emerged in the past few decades elevating it to at least the same level of effectiveness as individual psychotherapy (Burlingame \& Krogel, 2005; McRoberts et al., 1998). While individual psychotherapy often underlines the therapeutic relationship as the most important factor, group psychotherapy elevates group cohesion as the most important factor (Burlingame et al., 2002; Yalom \& Lesczc, 2005). Research has demonstrated a strong relationship between group cohesion and positive outcomes in group psychotherapy across various theoretical orientations (Burlingame et al., 2018).

Burlingame and Jensen (2017) write that "many disorders now have good or excellent evidence supporting group treatment's ability to lead to improved outcomes 
(panic, social phobia, OCD, eating disorders, substance abuse, trauma-related disorders, breast cancer, schizophrenia, and personality disorders)" (p. S200). More specifically, the group psychotherapy research has produced systematic reviews and metaanalyses outlining its efficacy in the treatment of panic disorder (Schwartze et al., 2017), anxiety (Barkowski et al., 2016), obsessive-compulsive disorder (Schwartze et al., 2016), depression (Huntley et al., 2012; Krishna et al., 2015; McDermut et al., 2001; Pearson \& Burlingame, 2013), bipolar disorder (Pearson \& Burlingame, 2013), post-traumatic stress disorder (Bisson et al., 2013; Schwartze et al., 2019; Sloan et al., 2013), and alcoholism/addiction (Coco et al., 2019). An evidence base has emerged to show no difference between the effectiveness of individual and group therapy approaches for mood disorders (Burlingame et al., 2004; Roselló et al., 2008), panic disorders (Sharp et al., 2004), personality disorders (Arnevik et al., 2009), schizophrenia (Lockwood et al., 2004), obsessive compulsive disorder (O'Leary et al., 2009), substance abuse (Burlingame et al., 2013; Panas et al., 2003), and eating disorders (Nevonen \& Broberg, 2006; Renjilian et al., 2001).

The group psychotherapy research has established its efficacy as compared to a waitlist, compared to alternative treatments, and through pre- to post-treatment tests (Burlingame et al., 2003). Group psychotherapy's effectiveness has been demonstrated across the treatment continuum from inpatient, residential, and outpatient contexts including university-based and prison counseling settings (Burlingame et al., 2003; Kosters et al., 2006). Burlingame and Jenson note that in the past 25 years, cognitive behavioral group therapy has dominated the research base in terms of quantity of publications with a five-to-one ratio compared to all other theoretical orientations (Burlingame \& Jensen, 2017).

\subsection{Humanistic-Experiential Psychotherapy Research}

Experiential psychotherapy contains multiple action-based approaches including psychodrama, gestalt therapy, existential therapy, humanistic therapy, and emotionfocused therapy. Experiential psychotherapy's efficacy has been demonstrated through multiple research studies which suggest it is at least equally efficacious as CBT, psychodynamic psychotherapy, and other talk therapy or behavioral approaches (Elliott, 1996, 2001; Elliott \& Freire, 2008; Elliott et al., 2004; Greenberg, 2013; Greenberg et al., 1994; Greenberg \& Malcolm, 2002; Greenberg \& Paivio, 1998; Greenberg et al., 1998; Mullings, 2017; Smith et al., 1980). A meta-analysis examining 86 studies, published Elliott et al. (2004), concluded that experiential therapies are statistically equal in effectiveness to talk therapies. They write in 2004 that "is now more than sufficient to warrant a positive valuation of experiential conclusion in four important areas: depression, anxiety disorders, trauma, and marital problems" (p. 423). Greenberg's (2013) chapter in Healing World Trauma with the Therapeutic Spiral Model positions the Therapeutic Spiral Model of psychodrama within this larger literature base of experiential psychotherapy research indicating that "there 
is now solid evidence for the efficacy and effectiveness of experiential therapies" (2013, p. 144).

Elliott et al. (2013) conducted a major meta-analysis in which they found that humanistic-experiential psychotherapies (HEP) were equally as efficacious as CBT for the treatment of depression and for coping with medical conditions, and superior to CBT in effectiveness for the treatment of interpersonal difficulties and unresolved relationship issues. In contrast, the meta-analysis found that HEPs were somewhat less effective than CBT in treating anxiety disorders, though still probably efficacious. Their meta-analysis also analyzed HEPs implementation with specific categories of mental health disorders based on Chambless and Hollon's criteria for efficacy (Chambless \& Hollon, 1998). Their outcomes suggest HEPs are specific and efficacious (the highest standard) in the treatment of depression and unresolved relationship issues while also probably efficacious in the treatment of anxiety and psychosis (Elliott et al., 2013; Mullings, 2017).

\subsection{Research on Drama Therapy, Creative Arts Therapies, and Body- and Movement-Oriented Therapies}

Similar to its relationship to humanistic-experiential psychotherapy, psychodrama is often categorized within the larger umbrellas of the creative arts therapies and the body- and movement-oriented intervention (BMOI). Many meta-analyses and systematic reviews categorize psychodrama and drama therapy in the same category as well. Feniger-Schaal and Orkibi (2020) published the first integrative systematic review on drama therapy interventions concluding that the evidence base is small but shows promising results, especially with populations with developmental disabilities, cognitive difficulties, and difficulties in verbal expression. Bourne et al. (2018) published a systematic analysis on drama therapy group work for adults with mental illness which concluded that drama therapy offers important social benefits, emotional support, self-awareness, creativity, and self-esteem. A 2013 literature review on the effectiveness of expressive arts therapies concluded that "overall, despite many inconclusive studies, the effectiveness of creative arts therapies for a range of conditions in indicated" (Dunphy et al., 2013).

One area that creative arts therapies and BMOI may be uniquely situated is in the treatment of PTSD and trauma-related issues. Baker et al. (2018), in their systematic review on PTSD and creative arts therapies, report that decreased PTSD symptoms may be related to symbolic and nonverbal expression of painful experiences through the creative arts therapies. Neuroscience research has demonstrated that PTSD symptoms are related to right hemisphere and limbic system brain structures only marginally impacted by cognition and verbal expression (Rauch et al., 1996; van der Kolk, 2014). Malchiodi (2014) writes that creative arts therapies may be effective for PTSD due to their nature of being right brain dominant. The creative arts allow clients to renegotiate trauma with containment, empowerment, control, 
and the playfulness of art-making (Baker et al., 2018). A recent systematic review and meta-analysis on treatment of PTSD with body-oriented and movement-oriented intervention (BMOI) concluded that BMOI as an adjunct treatment or stand-alone treatment may result in decreased PTSD symptoms (van de Kamp et al., 2019). The same study concluded that body-oriented therapies had smaller dropout rates than other PTSD treatments and other positive health outcomes. BMOI engages the traumatized limbic system and nervous system of the client using a bottom-up approach, while cognitive, verbal, and other top-down approaches primarily engage the prefrontal cortex (Levine, 2010; Ogden et al., 2006; van der Kolk, 2014).

\subsection{Psychodrama's Evidence Base}

The evidence base for psychodrama as a psychotherapy approach is limited, though continuously evolving and growing. Orkibi and Feniger-Schaal (2019), in their recent systematic review of the evidence base of psychodrama, state that "psychodrama intervention research in the last decade suggests there are promising results" (p. 1). Wieser's (2007) meta-analysis on psychodrama's efficacy as a psychotherapy approach indicated that although more rigorous and higher-quality research is needed, there is evidence of positive effects for various different mental health disorders. Wieser concludes that "neurotic, stress-related and somatoform disorders are the best validated area for psychodrama therapy" (2007, p. 278). A meta-analysis by Kipper and Ritchie concluded that psychodrama psychotherapy groups show an overall effect size "similar to, or better than that commonly reported for group psychotherapy in general" (2003, p. 1). They also stated that "although the initial empirical research on the effectiveness of psychodrama revealed some encouraging results, the data were insufficient" (Kipper \& Ritchie, 2003, p. 14). Similarly, Rawlinson's literature review (2000) determined "there is some research evidence to support the use of psychodrama" and that it may be best utilized "as a tool for helping people to develop self-esteem, to change elements of their behavior and to develop empathy and social relationships" (p. 93). Kellermann's review of psychodrama's evidence base noted its limitations while also stating "psychodrama was a very valid alternative to other therapeutic approaches, primarily in promoting behavior change with adjustment, antisocial, and related disorders" (1987, p. 467). Other studies include exploring sociometry and psychodrama's effectiveness in supervision (Daniel, 2016; Tabib, 2017) and educational settings (Azoulay \& Orkibi, 2018; Schnabel \& Reif, 2016; Veiga et al., 2015) while calling for increased research in these areas.

In the context of psychotherapy, the current evidence base of psychodrama as a treatment approach supports its effectiveness in treating depressive disorders (Avinger \& Jones, 2007; Carbonell \& Parteleno-Barehmi, 1999; Costa et al., 2006; Erbay et al., 2018; Hall, 1977; Rezaeian et al., 1997; Sharma, 2017; Smokowsky \& Bacallao, 2009; Souilm \& Ali, 2017; Wang et al., 2020; Wieser, 2007), anxiety and panic disorders (Avinger \& Jones, 2007; Carbonell \& Parteleno-Barehmi, 1999; 
Erbay et al., 2018; Hall, 1977; Park \& Lim, 2002; Schramski et al., 1984; Sharma, 2017; Smokowsky \& Bacallao, 2009; Tarashoeva et al., 2017; Wang et al., 2020), PTSD and trauma-related disorders (Bannister, 1990, 1991, 1997; Baumgartner, 1986; Burge, 1996; Clarke, 1993; Hudgins \& Drucker, 1998; Giacomucci \& Marquit, 2020; Hudgins et al., 2000; Lind et al., 2006; Paivio \& Greenberg, 1995), and schizophrenia, schizotypal, and delusional disorders (Harrow, 1952; Jones \& Peters, 1952; Parrish, 1959).

Psychodrama has also been found to have some effectiveness with various other psychosocial conditions including improving emotional or psychological stability (Carpenter \& Sandberg, 1985; Choi, 2003; Kang \& Son, 2004; Schmidt, 1978; White et al., 1982; Wood et al., 1979), interpersonal relationships (Bendel, 2017; Gow et al., 2011; Gow \& McVea, 2006; Petzold, 1979; Shim, 2002), improving conflict resolution skills (Karatas, 2011), increased self-esteem (Gow et al., 2011; Carbonell \& Parteleno-Barehmi, 1999), increasing empathy and self-awareness (Dogan, 2018),

In terms of populations, the psychodrama research base includes studies with various age groups, ethnicities, and social groups. A large majority of the research in the past decade (43\%) has focused on students and youth and demonstrates positive improvements in multiple areas (Daemi \& Rahimparvar, 2018; Orkibi \& FenigerSchaal, 2019). Other research has included promising results with prison inmates (Harkins et al., 2011; Schramski et al., 1984; Testoni et al., 2020) and adults coping with various medical conditions (Alby et al., 2017; Dehnavi et al., 2016; Karabilgin et al., 2012; Menichetti et al., 2016; Sproesser et al., 2010; Terzioglu \& Özkan, 2017). Smokowsky and Bacallao (2009) found a significant difference in effect between an action-based intervention program and a talk-based support groups for Latino families, and this effect favored the experiential groups in terms of decreasing anxiety, depression, and interpersonal conflict.

Multiple studies in the field of addictions have pointed to psychodrama's effectiveness in increasing quality of life (Dehnavi et al., 2016), enhancing motivation (Testoni et al., 2018), reducing depression (Dehnavi et al., 2015; Testoni et al., 2020), reducing aggression (Nooripour et al., 2016), and for relapse prevention (Somov, 2008). A recent study by Testoni et al. (2020) pointed to psychodrama's effectiveness for treating addiction in prison; they found it helped access emotions, increased social and emotional functioning, and decreased depressive, anxiety, and traumatic symptoms. Giacomucci and Marquit (2020) offer support for traumafocused psychodrama's effectiveness in treating PTSD in inpatient addiction settings. Though the utilization of psychodrama by addiction professionals gradually becomes more common (Dayton, 2005, 2015; Giacomucci, 2017, 2018, 2019, 2020; Giacomucci et al., 2018; Giacomucci \& Stone, 2019), few research studies have explored its effectiveness.

Kipper and Ritchie (2003) offer one of the only explorations of the effect of specific psychodrama interventions as compared to others. In their meta-analysis, they suggest that while the intervention of role-playing showed barely any improvement effect, "role reversal and doubling showed means suggesting large improvement effect size" (p. 19). Future research is needed to explore the effect of various psychodrama interventions used to varying degrees within psychodrama practice. 
Although the American community does not recognize psychodrama as an evidence-based practice, it has been accredited by other governments or insurance systems including in Austria (Ottomeyer et al., 1996), Hungary (Pinter, 2001), and the European Association of Psychotherapy (Cruz et al., 2018). Psychodrama was born in Austria but later developed as a psychotherapy approach in the USA after Jacob Moreno immigrated. Coincidentally, the USA lags behind other countries when it comes to producing and evaluating psychodrama research. It appears that the EBP movement of the 1990s led European psychodramatists to pursue psychodrama's validation as an evidence-based practice while as the same time it seems that psychodrama was never submitted for review as an evidence-based practice in the USA.

Orkibi and Feniger-Schaal (2019) note that in the past decade, 39\% of psychodrama research studies were from Turkey, 13\% from Italy, 10\% from Israel, and $10 \%$ from the USA. They also discovered that "psychodrama intervention research in the last decade has followed an upward trajectory" as the frequency of studies has increased from only one published in 2008 to eight in 2017 (Orkibi \& Feniger-Schaal, 2019, p. 21).

When it comes to quantitative psychodrama research, Kirk (2016) notes that psychodrama practitioners often struggle because of "the predominance of positivist quantitative research that seems apparently at odds with the philosophy and tenets of psychodrama" (p. 323). The psychodrama literature base is primarily composed of theoretical, philosophical, and practice-oriented publications-many of which include descriptions of client experiences and case studies. The literature focuses more on meaning than on measurements (Kirk, 2016). Some psychodrama researchers are suggesting qualitative research, the ideal research methodology for psychodrama because it would be able to "meet the spontaneous and creative approach of psychodrama" (Hintermeier, 2011). Dima and Bucuta (2016) suggest that the process-oriented nature of psychodrama is complimented by the processoriented nature of qualitative research methods. They also note that the majority of qualitative psychodrama studies are descriptive in nature and the field would benefit from deeper, interpretive qualitative psychodrama research.

When it comes to the embracing of qualitative research methods due to their complimentary nature to the values of the profession, social work and psychodrama share common ground. Both highlight the importance of making sense of the subjective experience of participants, exploring social context, and investigating the process-all of which seem to favor a qualitative research methodology.

\subsubsection{Psychodrama Research Limitations}

Many others have cited the need for future psychodrama research to be of higher quality and scientific rigor (Kellermann, 1987; Kipper \& Ritchie, 2003; Orkibi \& Feniger-Schaal, 2019; Wieser, 2007). Kellermann notes that "practitioners of psychodrama traditionally rely more on clinical experience than on experimental 
research data when advocating the effectiveness of this method. As a consequence, psychodrama literature mostly includes descriptive rather than empirical studies" (1987, p. 459).

At the same time, there are some inherent limitations to conducting research on psychodrama (Kellermann, 1992; Kipper \& Ritchie, 2003; Ridge, 2010). Psychodrama is process-oriented and based on spontaneity and creativity which means that psychodrama sessions are never identical (Giacomucci, 2019). A psychodrama session involves a variety of clinical interventions including roleplaying, role reversal, doubling (various types outlined in the literature), and mirroring. These interventions are utilized based on the facilitator's judgment throughout the process and sometimes spontaneously used by other participants as well. These factors make it quite difficult to manualize the psychodramatic approach which is often a prerequisite for evidence-based reviews.

Orkibi and Feniger-Schaal (2019) note that almost all psychodrama training takes place at private institutes focused on clinical applications rather than in research-focused university settings. Psychodrama's disconnection from academia makes it difficult for psychodramatists to have access to academic journals, Internal Review Boards (IRB), research support, and research funding. It appears that most psychodramatists are much more interested in practice than research and simply do not have the research training to design and conduct research studies. Buchanan and Taylor's (1986) study using the Myers-Briggs personality inventory with 170 certified psychodramatists (72.65\% of ABE certified psychodramatists at the time) indicated that they are $87 \%$ innovative vs conservative, $87 \%$ intuitive over sensing, $72 \%$ feeling-oriented over thinking-oriented, and $65 \%$ extraverted vs introverted. The innovative, intuitive, feeling-oriented, and extroverted personality types may be less likely to engage in research, which is inherently more sensing, thinking-oriented, and conservative. When questioned about psychodrama group psychotherapy research in 1957, Moreno comments on the differentiation between producers of art and analysts of art-suggesting that demonstrating or experiencing the method is superior to systematic analysis or theoretical publications of the method. He promotes direct experience, or existential validation, as greater in influence to scientific validation:

The combination of the professional skill of practicing group psychotherapy and the skill of scientific analysis is rare... It is very difficult to duplicate in written form the group experiences which take place in actual sessions. This is the meaning of my distinction between existential and scientific validation. (p 136)

It seems that the combined lack of research training, lack of access to university resources, and the personality types of most psychodramatists largely contribute to the absence of psychodrama research.

Orkibi and Feniger-Schaal (2019) also comment on the issue of psychodrama credentialing and training in the research. Though many are teaching, learning, and practicing psychodrama without certification, the American Board of Examiners in Sociometry, Psychodrama, and Group Psychotherapy note that they have certified over 400 professionals (not all of which are therapists), which is a small fraction of 
the total number of certified practitioners in other modalities. Multiple CBT credentialing boards in the USA indicate that they have certified several thousand CBT therapists and that over a thousand scientific studies of CBT have been published. In comparison, the small number of certified psychodramatists only contributes to the limitations of conducting research studies on psychodrama. In an attempt to bridge the gap between psychodrama and CBT, Treadwell has developed a Cognitive Experiential Group Therapy (CEGT) model which unites CBT content with psychodrama processes (2020).

\subsection{Moreno the Researcher}

While some have critiqued Moreno for his lack of attention to research, a simple review of his early professional career demonstrates his experience as a researcher in various roles beginning in medical school where he was a research assistant in an Austrian psychiatric clinic (Moreno, 2019). In his autobiography, he later writes of this experience stating that "I have always been appalled at the idea of experimenting on helpless mental patients" (2019, p. 185). Upon completion of his medical degree, Moreno turned his research focus to the theater where he explored measurements of time, space, and interaction between his actors at the Theater of Spontaneity. After immigrating to the USA, he was appointed to the role of Director of Social Research of the New York State Department of Welfare where he primarily worked at Sing Sing Prison and New York State Training School for Girls. The presentation of his Sing Sing Prison research resulted in the First Book on Group Psychotherapy (1932/1957), and his research from the New York Training School for Girls became foundational to his sociometric method and his book Who Shall Survive? (1934).

Since Moreno's research in Who Shall Survive? (1934) was published, sociometry and psychodrama appear to have been considered for their potential as research methodologies. By 1940, other writers were commenting on the potential utility of sociometry and psychodrama as research instruments- "The research value of sociometry is not doubted. The sociometric tests and re-tests have given us reliable data in the form of. psychological networks, social atoms, isolates, and leadership structures in groups. In a different way, psychodrama offers to give us information about processes going on within the social atom" (Franz, 1940, p. 59). Moreno (1947) highlights the contributions of sociometry to sociology research with groups, intergroup relations, and social networks, while later in 1950, Borgatta highlights the potential of psychodrama and sociodrama in social psychology research. Moreno posits sociometry as a theory of human relations and "a central research technology for the social sciences" (1954, p. 185). It also appears that in the 1990s with the re-emergence of EBP and new computer technologies the utility of sociometry as research instruments was reconsidered (Treadwell et al., 1997). Various sociometric tools appear to have been integrated as research tools in the fields of education (Avramidis et al., 2017; Ferrandiz-Vindel \& Jimenez, 2011), counseling (Koehly \& Shivy, 1998), psychology (Terry, 2000), sociology (Tubaro et al., 2016), social 
network analysis (Grunspan et al., 2014; Hare, 1991; Jones, 2006; Treadwell et al., 1992), and business (Adams et al., 1994; Lucius \& Kuhnert, 1997; Waber et al., 2007).

Moreno argues that the previous methodologies used for research in psychology, biology, and medicine were insufficient for human groups and that the scientific laboratory could not recreate real conditions for adequately researching interpersonal relations. Instead, he suggests the theater as a research vehicle-one that has already been used for centuries for "acting out of the problems of society of the human society in miniature within a setting removed from reality" (Moreno, 1954, p. 182). $\mathrm{He}$ also promotes sociometry as a research method that mitigates this problem of research in the social sciences:

\footnotetext{
Until recently we had only two alternatives, the clinical method, maintaining the contact with social reality, however primitive the analysis of the scientific data might have been, or the laboratory method, overly scientific but sterile. But now we have a way out, a third alternative between these two extremes, the inhumanity of the experimental laboratory and the overhumanity and magic of the medical office; this way out is the sociometric revision of the experimental method. (Moreno, 1978, p. 679)
}

He writes that his new theory of research using sociometry and psychodrama offered two major shifts: "(1) Change the status of the research subjects and turn them into research partners and social investigators and (2) change the status of the social investigator and turn him into a research subject and participant actor" (1954, p. 182). Moreno's research philosophy mirrors his approach to group psychotherapy, elevating all participants to the same status as the facilitator.

Moreno's writings about research seem to reflect the method of Participatory Action Research (PAR), an inclusive approach to research that emphasizes community engagement in the research process while empowering participants as coresearchers and agents of social change (Kemmis et al., 2013). Most publications on the history of PAR attribute Kurt Lewin with its development in the 1940s; others have noted the influence Moreno had upon Lewin through his 1934 sociometry research in Who Shall Survive? and their multiple meetings in New York in 1935 (Greenwood, 2015; Gunz, 1996; Kemmis et al., 2013; Moreno, 1953, 2019; Renouvier, 1958). While some criticize Moreno for his lack of scientific rigor and his defiance of academic norms, in The Sage Handbook of Action Research, Greenwood (2015) acknowledges Moreno's often-forgotten contribution stating, "he did not abandon science but desired to create a humane social science" (p. 430).

It seems that when it came to the topic of research, Moreno primarily wrote of the process of using sociometry and psychodrama as research instruments rather than assessing the effectiveness of sociometry or psychodrama as psychotherapy approaches. Had he lived another decade and been influenced by the emerging empirical clinical practice movement of the late 1960s, we might speculate that he may have turned his attention to researching the effectiveness of his methods in psychotherapy. Others may argue against this citing his emphasis on psychodrama as much more than just an approach to psychotherapy, but a way of life. Nevertheless, social work's shift away from the psychoanalytic perspective toward an empirically validated approach in the 1960s was a missed opportunity for psychodrama to become 
embedded within the social work field — as outlined previously, social workers would have found psychodrama's philosophy and theory complimentary. Instead, social work turned to the empirically supported behavioral and later cognitive behavioral therapies as a new source of authority and a vehicle for professionalizing. Similar to social work's adoption of psychoanalytic theory in the 1930s as an attempt to establish itself as a recognized profession, this push to professionalize in the 1960s also further separated the fields of social work and psychodrama (Schwinger, 2014). As the wave of influence from the evidence-based practice movement in the 1990s and 2000s expanded, psychodrama in the USA simultaneously lost its popularity and momentum.

\subsection{Conclusion}

The evidence-based practice movement emerged with the goal of critically evaluating the effectiveness of practice to enhance the field and protect society from harmful practices. EBP challenges social work and psychodrama practitioners to reflect on the effectiveness of their approaches while considering how the growing bodies of research literature might guide practice. Social work's ongoing attempts to professionalize and obtain legitimacy within the larger field influenced its adoption of EBP and cognitive behavioral therapies which have, in some ways, threatened its core values. The prevalence of cognitive behavioral therapies in social work seems to have further marginalized psychodrama and sociometry while have failed to adequately respond to the demands of EBP in the USA. At the same time, it seems that social work and psychodrama find common ground in the complimentary nature of qualitative methods. Though Jacob Moreno's early career was researchoriented, he seemed entirely focused on using his methods as research processes rather than researching the effectiveness of them. His position that existential validation is superior to scientific validation seems to be replicated by the generations of psychodramatists that have come after him. Nevertheless, the past decade has seen an increase in quantitative psychodrama research, primarily in Asia and Europe, which has the potential of enhancing the scientific validity of psychodrama around the world. More psychodrama research is needed with higher-quality research designs to establish psychodrama as an evidence-based practice.

\section{References}

Adams, G. A., Elacqua, T. C., \& Colarelli, S. M. (1994). The employment interview as a sociometric selection technique. Journal of Group Psychotherapy, Psychodrama \& Sociometry, 47(3), 99113.

Adams, K. B., Matto, H. C., \& LeCroy, C. W. (2009). Limitations of evidence based practice for social work education: Unpacking the complexity. Journal of Social Work Education, 45(2), $165-186$. 
Alby, F., Angelici, G., Picinotti, S., \& Zucchermaglio, C. (2017). A pilot study on an analytic psychodrama group for cancer patients and family members. Rassegna di Psicologia, 34(1), 67-77.

Arnevik, E., Wilberg, T., Urnes, Ø., Johansen, M., Monsen, J. T., \& Karterud, S. (2009). Psychotherapy for personality disorders: Short-term day hospital psychotherapy versus outpatient individual therapy-A randomized controlled study. European Psychiatry, 24, 71-78.

Avinger, K., \& Jones, R. (2007). Group treatment of sexually abused adolescent girls: A review of outcome studies. American Journal of Family Therapy, 35, 315-326.

Avramidis, E., Strogilos, V., Aroni, K., \& Kantaraki, C. T. (2017). Using sociometric techniques to assess the social impacts of inclusion: Some methodological considerations. Educational Research Review, 20, 68-80.

Azoulay, B., \& Orkibi, H. (2018). Helpful and hindering factors in psychodrama field training: A longitudinal mixed methods study of student development. Frontiers in Psychology, 9, 196.

Baker, F. A., Metcalf, O., Varker, T., \& O'Donnell, M. (2018). A systematic review of the efficacy of creative arts therapies in the treatment of adults with PTSD. Psychological Trauma: Theory, Research, Practice, and Policy, 10(6), 643.

Bannister, A. (1990). From hearing to healing: Working with the aftermath of childhood sexual abuse. Chichester: Wiley.

Bannister, A. (1991). Learning to live again: Psychodramatic techniques with sexually abused young people. In P. Holmes \& M. Karp (Eds.), Psychodrama: Inspiration and technique. London: Tavistock/Routledge.

Bannister, A. (1997). The healing drama: Psychodrama and dramatherapy with abused children. London: Free Association Books.

Barkowski, S., Schwartze, D., Strauss, B., Burlingame, G. M., Barth, J., \& Rosendahl, J. (2016). Efficacy of group psychotherapy for social anxiety disorder: A meta-analysis of randomizedcontrolled trials. Journal of Anxiety Disorders, 39, 44-64.

Baumgartner, D. (1986). Sociodrama and the Vietnam combat veteran: A therapeutic release for a wartime experience. Journal of Group Psychotherapy and Sociometry, 38, 31-39.

Bendel, K. E. (2017). Social work and Moreno: A systematic review of psychodrama methods and implications. ProQuest Dissertations and Theses. Retrieved from https://proxy.library.upenn.edu: 7450/docview/1920065271? accountid=14707.

Berger, R. (2010). EBP: Practitioners in search of evidence. Journal of Social Work, 10(2), 175-191.

Bisson, J. I., Roberts, N. P., Andrew, M., Cooper, R., \& Lewis, C. (2013). Psychological therapies for chronic post-traumatic stress disorder (PTSD) in adults. Cochrane Database of Systematic Reviews, Issue 12. Art. No.: CD003388.

Bledsoe-Mansori, S. E., Manuel, J. I., Bellamy, J. L., Fang, L., Dinata, E., \& Mullen, E. J. (2013). Implementing evidence-based practice: Practitioner assessment of an agency-based training program. Journal of Evidence-Based Social Work, 10, 73-90.

Borgatta, E. (1950). The use of psychodrama, sociodrama and related techniques in social psychological research. Sociometry, 13(3), 244-258.

Borntrager, C. F., Chorpita, B. F., Higa-McMillan, C., \& Weisz, J. R. (2009). Provider attitudes toward evidence-based practices: Are the concerns with the evidence or with the manuals? Psychiatric Services, 60(5), 677-681.

Bourne, J., Andersen-Warren, M., \& Hackett, S. (2018). A systematic review to investigate dramatherapy group work with working age adults who have a mental health problem. The Arts in Psychotherapy, 61, 1-9.

Briar, S. (1967). The current crisis in social casework. In A. M. Pins \& the Editorial Committee of the National Conference on Social Welfare (Eds.), Social Work Practice. (pp. 19-33). New York: Columbia University Press.

Bronson, D. E., \& Blythe, B. J. (1987). Computer support for single-case evaluation of practice. Social Work Research and Abstracts, 23(3), 10-13.

Buchanan, D., \& Taylor, J. (1986). Jungian typology of professional psychodramatists: Myers-briggs type indicator analysis of certified psychodramatists. Psychological Reports, 58(2), 391-400. 
Burge, M. (1996). The Vietnam veteran and the family 'both victims of post traumatic stress' - a psychodramatic perspective. The Australian and Aotearoa New Zealand Psychodrama Association, 5, 25-36.

Burlingame, G., Fuhriman, A., \& Johnson, J. (2002). Cohesion in group psychotherapy. In J. C. Norcross (Ed.), Psychotherapy relationships that work (pp. 71-87). New York, NY: Oxford University Press.

Burlingame, G., Fuhriman, A., \& Mosier, J. (2003). The differential effectiveness of group psychotherapy: A meta-analytic perspective. Group Dynamics: Theory, Research, and Practice, 7(1), 3-12.

Burlingame, G. M., \& Jensen, J. L. (2017). Small group process and outcome research highlights: A 25-year perspective. International Journal of Group Psychotherapy, 67(1), S194-S218.

Burlingame, G., \& Krogel, J. (2005). Relative efficacy of individual versus group psychotherapy. International Journal of Group Psychotherapy, 55(4), 607-611.

Burlingame, G., MacKenzie, K. R., \& Strauss, B. (2004). Small group treatment: Evidence for effectiveness and mechanisms of change. Handbook of Psychotherapy and Behavior Change (pp. 647-696).

Burlingame, G. M., McClendon, D. T., \& Yang, C. (2018). Cohesion in group therapy: A metaanalysis. Psychotherapy, 55(4), 384.

Burlingame, G., Strauss, B., \& Joyce, A. (2013). Change mechanisms and effectiveness of small group treatments. In M. J. Lambert (Ed.), Bergin and Garfield's handbook of psychotherapy and behavior change (6th ed., pp. 640-689). New York, NY: Wiley.

Carbonell, D. M., \& Parteleno-Barehmi, C. (1999). Psychodrama groups for girls coping with trauma. The International Journal of Group Psychotherapy, 49(3), 285-306.

Carpenter, P., \& Sandberg, S. (1985). Further psychodrama with delinquent adolescents. Adolescence, 20, 599-604.

Chambless, D. L., \& Hollon, S. D. (1998). Defining empirically supported therapies. Journal of Consulting and Clinical Psychology, 66(1), 7-18.

Cheetham, J. (1992). Evaluating social work effectiveness. Research on Social Work Practice, 2(3), 265-287.

Choi, H. J. (2003). Psychodrama: Theory and practice. Hakjisa: Seoul, Republic of Korea.

Clarke, K. M. (1993). Creation of meaning in incest survivors. Journal of Cognitive Psychotherapy, 7, 195-203.

Coco, G. L., Melchiori, F., Oieni, V., Infurna, M. R., Strauss, B., Schwartze, D., .. \& \& Gullo, S. (2019). Group treatment for substance use disorder in adults: A systematic review and meta-analysis of randomized-controlled trials. Journal of Substance Abuse Treatment, 99, 104-116.

Costa, E., Antonio, R., Soares, M., \& Moreno, R. (2006). Psychodramatic psychotherapy combined with pharmacotherapy in major depressive disorder: an open and naturalistic study. Revista Brasileira de Psiquiatria, 28(1), 40-43.

Council on Social Work Education, Commission on Accreditation. (1988). Handbook of accreditation standards and procedures. Washington, D.C.: Council on Social Work Education.

Cruz, A., Sales, C., Alves, P., \& Moita, G. (2018). The core techniques of Morenian psychodrama: A systematic review of literature. Frontiers in Psychology, 9, 1263. https://doi.org/10.3389/fpsyg. 2018.01263.

Daemi, F., \& Vasegh Rahimparvar, S. F. (2018). The Effects of Psychodrama on the Health of Adolescent Girls: A Systematic Review. Journal of Client-Centered Nursing Care, 4(1), 13-20.

Daniel, S. (2016). The usefulness of role reversal in one-to-one supervision: a qualitative research project using heuristic enquiry. In Psychodrama. Empirical Research and Science 2 (pp. 235253). Wiesbaden: Springer.

Dayton, T. (2005). The Living Stage: A step-by-step guide to psychodrama, sociometry, and experiential group therapy. Deerfield, FL: Health Communications Inc.

Dayton, T. (2015). Neuro-psychodrama in the treatment of relational trauma: A strength-based, experiential model for healing PTSD. Deerfield Beach, FL: Health Communications Inc. 
Dehnavi, S., Ayazi, N. M., \& Bajelan, M. (2015). The effectiveness of psychodrama in relapse prevention and reducing depression among opiate-dependent men. Journal of Addiction Studies, 9(34), 111-121.

Dehnavi, S., Hashemi, S. F., \& Zadeh-Mohammadi, A. (2016). The effectiveness of psychodrama on reducing depression among multiple sclerosis patients. International Journal of Behavioral Sciences, 9(4), 32-35.

Dima, G., \& Bucuță, M. D. (2016). The method of interpretative phenomenological analysis in psychodrama research. Zeitschrift für Psychodrama und Soziometrie, 15(1), 69-81.

Dogan, T. (2018). The effects of the psychodrama in instilling empathy and self-awareness: A pilot study. PsyCh Journal. https://doi.org/10.1002/pchj.228.

Drisko, J. W., \& Grady, M. D. (2015). Evidence-based practice in social work: A contemporary perspective. Clinical Social Work Journal, 43(3), 274-282.

Dunphy, K., Mullane, S., \& Jacobsson, M. (2013). The effectiveness of expressive arts therapies: A review of the literature. Melbourne: PACFA.

Elliott, R. (1996). Are client-centered/experiential therapies effective? A meta-analysis of outcome research. In U. Esser, H. Pabst, \& G-W. Speierer (Eds.), The power of the person-centered approach: New challenges-perspectives-answers (pp. 125-138). Koln, Germany: GwG Verlag.

Elliott, R. (2001). Research on the effectiveness of humanistic therapies: A meta-analysis. In D. J. Cain \& J. Seeman (Eds.), Humanistic psychotherapies: Handbook of research and practice (pp. 57-81). Washington, DC: American Psychological Association.

Elliott, R., \& Freire, E. (2008). Person-centered/experiential therapies are highly effective: Summary of the 2008 meta-analysis. Person-Centered Quarterly, November 1-3.

Elliott, R., Greensberg, L., \& Lietaer, G. (2004). Research on experiential psychotherapy. In M. Lambert, A. Bergin, \& S. Garfield (Eds.), Handbook of psychotherapy and behavior change. New York, NY: Wiley.

Elliott, R., Watson, J., Greenberg, L. S., Timulak, L., \& Freire, E. (2013). Research on humanisticexperiential psychotherapies. In M. J. Lambert (Ed.), Bergin \& Garfield's Handbook of psychotherapy and behavior change (6th ed., pp. 495-538). New York: Wiley.

Erbay, L. G., Reyhani, İ., Ünal, S., Özcan, C., Özgöçer, T., Uçar, C., et al. (2018). Does psychodrama affect perceived stress, anxiety-depression scores and saliva cortisol in patients with depression? Psychiatry Investigation, 15(10), 970-975.

Feniger-Schaal, R., \& Orkibi, H. (2020). Integrative systematic review of drama therapy intervention research. Psychology of Aesthetics, Creativity, and the Arts, 14(1), 68-80.

Ferrandiz-Vindel, I.-M., \& Jimenez, B. C. (2011). The sociogram: The analysis of interpersonal relationships in higher education. Journal of International Education Research (JIER), 7(5), 9-14.

Fischer, J. (1973). Is casework effective? A Review. Social Work, 18(1), 5-20.

Fishcer, J. (1978). Does anything work? Journal of Social Service Research, 1(3), 215-243.

Fortune, A. E., Reid, W. J., \& Miller, R. L., Jr. (2013). Qualitative research in social work. New York: Columbia University Press.

Franz, J. (1940). The place of the psychodrama in research. Sociometry, 3(1), 49-61.

Giacomucci, S. (2017). The sociodrama of life and death: Young adults and addiction treatment. The Journal of Psychodrama, Sociometry, and Group Psychotherapy, 65(1), 137-143. https:// doi.org/10.12926/0731-1273-65.1.137.

Giacomucci, S. (2018). The trauma survivor's inner role atom: A clinical map for post-traumatic growth. Journal of Psychodrama, Sociometry, and Group Psychotherapy, 66(1), 115-129.

Giacomucci, S. (2019). Social group work in action: A sociometry, psychodrama, and experiential trauma therapy curriculum. Doctorate in Social Work (DSW) Dissertations. 124. https://reposi tory.upenn.edu/cgi/viewcontent.cgi? article $=1128 \&$ context=edissertations_sp2.

Giacomucci, S. (2020). Addiction, traumatic loss, and guilt: A case study resolving grief through psychodrama and sociometric connections. The Arts in Psychotherapy, 67, 101627. https://doi. org/10.1016/j.aip.2019.101627. 
Giacomucci, S., Gera, S., Briggs, D., \& Bass, K. (2018). Experiential addiction treatment: Creating positive connection through sociometry and Therapeutic Spiral Model safety structures. Journal of Addiction and Addictive Disorders, 5, 17. http://doi.org/10.24966/AAD-7276/100017.

Giacomucci, S., \& Marquit, J. (2020). The effectiveness of trauma-focused psychodrama in the treatment of PTSD in inpatient substance abuse treatment. Frontiers in Psychology, 11, 896. https://dx.doi.org/10.3389\%2Ffpsyg.2020.00896.

Giacomucci, S., \& Stone, A. M. (2019). Being in two places at once: Renegotiating traumatic experience through the surplus reality of psychodrama. Social Work with Groups, 42(3), 184-196. https://doi.org/10.1080/01609513.2018.1533913.

Gilgun, J. (1994). Hand into glove. The grounded theory approach and social work practice research. In E. Sherman \& W. J. Reid (Eds.), Qualitative research in social work (pp. 115-125). New York: Columbia University Press.

Glass, G. V. (1976). Primary, secondary, and meta-analysis of research. Educational Researcher, $5(10), 3-8$.

Glisson, C. A. (1982). Notes on advanced social work education: Research teaching in social work doctoral programs. Social Service Review, 56(4), 629-639.

Goldstein, E. G., Miehls, D., \& Ringel, S. (2009). Advanced clinical social work practice: Relational principles and techniques. New York, NY: Columbia University Press.

Gow, K., Lowe, R., \& McVea, C. S. (2011). Corrective interpersonal experience in psychodrama group therapy: A comprehensive process analysis of significant therapeutic events. Psychotherapy Research, 21(4), 416-429.

Gow, K., \& McVea, C. (2006). Healing a Mother's emotional pain: Protagonist and director recall of a therapeutic spiral model (TSM) session. Journal of Group Psychotherapy, Psychodrama \& Sociometry, 59(1), 3-22.

Gray, M., Plath, D., \& Webb, S. (2009). Evidence-based social work: A critical stance. New York: Routledge.

Greenberg, L. S. (2013). Anchoring the therapeutic spiral model into research on experiential psychotherapies. In K. Hudgins \& F. Toscani (Eds.), Healing world trauma with the therapeutic spiral model. Psychodramatic stories from the frontlines (pp. 132-148). Philadelphia: Jessica Kingsley Publishing.

Greenberg, L. S., \& Malcolm, W. (2002). Resolving unfinished business: Relating process to outcome. Journal of Consulting and Clinical Psychology, 70, 406-416.

Greenberg, L. S., Elliott, R., \& Lietaer, G. (1994). Research on humanistic and experiential psychotherapies. In A. E. Bergin \& S. L. Garfield (Eds.), Handbook of psychotherapy and behavior change (4th ed., pp. 509-539). New York: Wiley.

Greenberg, L. S., \& Paivio, S. C. (1998). Allowing and accepting painful emotional experiences. Journal of Group Psychotherapy, Psychodrama and Sociometry, 51(2), 47.

Greenberg, L. S., Watson, J., \& Lietaer, G. (1998). Handbook of experiential psychotherapy. New York: Guilford Press.

Greenwood, D. J. (2015). Evolutionary systems thinking: What Gregory Bateson, Kurt Lewin, and Jacob Moreno offered to action research that still remains to be learned. In H. Bradbury (Ed.), Handbook of action research (3rd ed., pp. 425-433). London: Sage Publications.

Grunspan, D. Z., Wiggins, B. L., \& Goodreau, S. M. (2014). Understanding classrooms through social network analysis: A primer for social network analysis in education research. CBE-Life Sciences Education, 13(2), 167-178.

Gunz, J. (1996). Jacob L. Moreno and the origins of action research. Educational Action Research, $4(1), 145-148$.

Hall, I. (1977). The effects of an intensive weekend psychodrama vs. spaced psychodrama sessions on anxiety, distress and attitude toward group interaction in nursing students. Unpublished doctoral dissertation, University of New Mexico.

Hare, A. P. (1991). Sociometry and small group research: A footnote to history. Journal of Group Psychotherapy, Psychodrama \& Sociometry, 44(2), 87-91. 
Harkins, L., Pritchard, C., Haskayne, D., Watson, A., \& Beech, A. R. (2011). Evaluation of geese theatre's re-connect program: Addressing resettlement issues in prison. International Journal of Offender Therapy and Comparative Criminology, 55(4), 546-566.

Harrow, G. (1952). Psychodrama group therapy: Its effect upon the role behavior of schizophrenic patients. Group Psychotherapy, 5, 120-172.

Haynes, R., Devereaux, P., \& Guyatt, G. (2002). Clinical expertise in the era of evidence basedmedicine and patient choice. Evidence-Based Medicine, 7, 36-38.

Hintermeier, S. (2011). Qualitative psychodramaforschung. Zeitschrift für Psychodrama und Soziometrie, 10(1), 89-107.

Holmes, S. E., \& Kivlighan, D. M., Jr. (2000). Comparison of therapeutic factors in group and individual treatment processes. Journal of Counseling Psychology, 47(4), 478-484. https://doi. org/10.1037/0022-0167.47.4.478.

Hudgins, M. K., \& Drucker, K. (1998). The containing double as part of the therapeutic spiral model for treating trauma survivors. The International Journal of Action Methods, 51(2), 63-74.

Hudgins, M. K., Drucker, K., \& Metcalf, K. (2000). The containing double: A clinically effective psychodrama intervention for PTSD. The British Journal of Psychodrama and Sociodrama, 15(1), $58-77$.

Huntley, A. L., Araya, R., \& Salisbury, C. (2012). Group psychological therapies for depression in the community: Systematic review and meta-analysis. The British Journal of Psychiatry, 200(3), $184-190$.

Jones, D. (2006). Sociometry and social network analysis: Applications and implications. Australian and Aotearoa New Zealand Psychodrama Association Journal, 15, 76.

Jones, F. D., \& Peters, H. N. (1952). An experimental evaluation of group psychotherapy. Journal of Abnormal and Social Psychology, 47, 345-353.

Kang, S. H., \& Son, C. N. (2004). The effect of psychodrama on the alexithymia, somatization and quality of life of college students. Korean Journal of Health Psychology, 9(2), 243-263.

Karabilgin, O. S., Gokengin, G. B., Doğaner, İ., \& Gokengin, D. (2012). The effect of psychodrama on people living with HIV/AIDS. European Journal of Psychotherapy \& Counselling, 14(4), $317-333$.

Karatas, Z. (2011). Investigating the effects of group practice performed using psychodrama techniques on adolescents' conflict resolution skills. Educational Sciences: Theory and Practice, 11(2), 609-614.

Karatas, Z., \& Gokcakan, Z. (2009). A comparative investigation of the effects of cognitivebehavioral group practices and psychodrama on adolescent aggression. Educational Sciences: Theory and Practice, 9(3), 1441-1452.

Kellermann, P. F. (1987). Outcome research in classical psychodrama. Small Group Research, 18(4), 459-469.

Kellermann, P. F. (1992). Focus on psychodrama: The therapeutic aspects of psychodrama. London, UK: Jessica Kingsley.

Kemmis, S., McTaggart, R., \& Nixon, R. (2013). The action research planner: Doing critical participatory action research. Chicago, IL: Springer.

Kipper, D., \& Ritchie, T. (2003). The effectiveness of psychodramatic techniques: A meta-analysis. Group Dynamics: Theory, Research and Practice, 7(1), 13-25.

Kirk, K. (2016). Grasping the tail of a comet: Researching and writing about psychodrama in the 21st century. In Psychodrama. Empirical Research and Science 2 (pp. 323-325). Wiesbaden: Springer.

Koehly, L. M., \& Shivy, V. A. (1998). Social network analysis: A new methodology for counseling research. Journal of Counseling Psychology, 45(1), 3-17.

Kosters, M., Burlingame, G., Nachtigall, C., \& Strauss, B. (2006). A meta-analytic review of the effectiveness of inpatient group psychotherapy. Group Dynamics-Theory Research and Practice, $10(2), 146-163$. 
Krishna, M., Lepping, P., Jones, S., \& Lane, S. (2015). Systematic review and meta-analysis of group cognitive behavioural psychotherapy treatment for sub-clinical depression. Asian Journal of Psychiatry, 16, 7-16.

Laska, K. M., Gurman, A. S., \& Wampold, B. E. (2014). Expanding the lens of evidence-based practice in psychotherapy: A common factors perspective. Psychotherapy, 51(4), 467.

Levine, P. A. (2010). In an unspoken voice: How the body releases trauma and restores goodness. Berkeley, CA: North Atlantic Books.

Lind, M., Renner, W., \& Ottomeyer, K. (2006). Die Wirksamkeit psychodramatischer Gruppentherapie bei traumatisierten MigrantInnen-eine Pilotstudie [How effective is psychodramatic group therapy with traumatized migrants? A pilot study]. Zeitschrift für Psychotraumatologie und Psychologische Medizin, 4, 75-91.

Lockwood, C., Page, T., \& Conroy-Hiller, T. (2004). Effectiveness of individual therapy and group therapy in the treatment of schizophrenia. JBI Reports, 2, 309-338.

Lucius, R. H., \& Kuhnert, K. W. (1997). Using sociometry to predict team performance in the work place. The Journal of Psychology, 131(1), 21-32.

Magill, M. (2006). The future of evidence in evidence-based practice: Who will answer the call for clinical relevance? Journal of Social Work, 6(2), 101-115.

Malchiodi, C. A. (2014). Neurobiology creative interventions, and childhood trauma. In C. A. Malchiodi (Ed.), Creative interventions with traumatized children (pp. 3-23). New York, NY: Guilford Press.

Manuel, J. I., Mullen, E. J., Fang, L., Bellamy, J. L., \& Bledsoe, S. E. (2009). Preparing social work practitioners to use evidence-based practice. Research on Social Work Practice, 19(5), 613-627.

McDermut, W., Miller, I. W., \& Brown, R. A. (2001). The efficacy of group psychotherapy for depression: A meta-analysis and review of the empirical research. Clinical Psychology: Science and Practice, 8(1), 98-116.

McNeece, C. A., \& Thyer, B. A. (2004). Evidence-based practice and social work. Journal of Evidence-Based Social Work, 1(1), 7-25.

McRoberts, C., Burlingame, G., \& Hoag, M. (1998). Comparative efficacy of individual and group psychotherapy: A meta-analytic perspective. Group Dynamics: Theory, Research, and Practice, 2(2), 101-117.

Menichetti, J., Giusti, L., Fossati, I., \& Vegni, E. (2016). Adjustment to cancer: Exploring patients' experiences of participating in a psychodramatic group intervention. European Journal of Cancer Care, 25(5), 903-915.

Messer, S. B., \& Wampold, B. E. (2002). Let's face facts: Common factors are more potent than specific therapy ingredients. Clinical Psychology: Science and Practice, 9(1), 21-25.

Moreno, J. L. (1934). Who shall survive? A new approach to the problems of human interrelations. Washington, D.C.: Nervous and Mental Disease Publishing Co.

Moreno, J. (1947). Contributions of sociometry to research methodology in sociology. American Sociological Review, 12, 287-292.

Moreno, J. (1953). How Kurt Lewin's "research center for group dynamics" started. Sociometry, 16(1), 101-104.

Moreno, J. (1954). Old and new trends in sociometry: Turning points in small group research. Sociometry, 71(2), 179-193.

Moreno, J. L. (1957). The first book on group psychotherapy (3rd ed.). Beacon, NY: Beacon House.

Moreno, J. L. (1978). Who shall survive?: Foundations of sociometry, group psychotherapy and psychodrama (3rd ed.). Beacon, NY: Beacon House.

Moreno, J. L. (2019). In E. Schreiber, S. Kelley, \& S. Giacomucci (Eds.), The autobiography of a genius. United Kingdom: North West Psychodrama Association.

Mullings, B. (2017). A literature review of the evidence for the effectiveness of experiential psychotherapies. Melbourne: PACFA.

Nevonen, L., \& Broberg, A. G. (2006). A comparison of sequenced individual and group psychotherapy for patients with bulimia nervosa. International Journal of Eating Disorders, $39,117-127$. 
Nooripour, R., Rahmani, S., Tavalaei, S. A., Alikhani, M., \& Hosseinian, S. (2016). Effectiveness of psychodrama on aggression of female addicts with bipolar personality. J Addiction Prevention, $4(1), 4$.

Norcross, J. C., \& Lampbert, M. J. (2011). Evidence-based therapy relationships. In J. C. Norcross (Ed.), Psychological relationships that work: Evidence-based responsiveness (2nd ed., pp. 3-21). New York: Oxford University Press.

O'Leary, E. M. M., Barrett, P., \& Fjermestad, K. W. (2009). Cognitive-behavioral family treatment for childhood obsessive-compulsive disorder: A 7-year follow-up study. Journal of Anxiety Disorders, 23, 973-978.

Ogden, P., Pain, C., \& Fisher, J. (2006). A sensorimotor approach to the treatment of trauma and dissociation. Psychiatric Clinics of North America, 29(1), 263-279.

Okpych, N. J., \& Yu, J. L. (2014). A historical analysis of evidence-based practice in social work: The unfinished journey toward an empirically grounded profession. Social Service Review, 88(1), 3-58.

Orkibi, H., \& Feniger-Schaal, R. (2019). Integrative systematic review of psychodrama psychotherapy research: Trends and methodological implications. PLoS ONE, 14(2), e0212575. https://doi.org/10.1371/journal.pone.0212575.

Ottomeyer, K., Wieser, M., mit einem Beitrag von Jorda, C. \& unter Mitwirkung der AusbildungsleiterInnen für Psychodrama im ÖAGG. (1996). Dokumentation - Informationspapier über die metho $\neg$ denspezifische Ausrichtung des Psychodramas, Rollenspiels und der Soziometrie. Einleitung A. Schigutt. Psychodrama. Zeitschrift für Theorie und Praxis, 9, 185-222.

Padgett, D. K. (1998). Does the glove really fit? Qualitative research and clinical social work practice. Social Work, 43(4), 373-381.

Panas, L., Caspi, Y., Fournier, E., \& McCarty, D. (2003). Performance measures for outpatient substance abuse services. Journal of Substance Abuse Treatment, 25, 271-278.

Paivio, S. C., \& Greenberg, L. (1995). Resolving "unfinished business": Efficacy of experiential therapy using empty-chair dialogue. Journal of Consulting and Clinical Psychology, 63, 419-425.

Park, H. S., Lim S. J. (2002). The effects of psychodrama on depression level, social support, self-esteem, and stress in depressed college students. Korean Journal of Psychodrama, 5(1), 93-115.

Parrish, M. M. (1959). The effect of short-term psychodrama on chronic schizophrenic patients. Group Psychotherapy, 12, 15-26.

Pearson, M., \& Burlingame, G. (2013). Cognitive approaches to group therapy: Prevention of relapse in major depressive and bipolar disorders. International Journal of Group Psychotherapy, 63(2), 303-309.

Petzold, H. (1979). Psychodrama-therapie: Theorie, Methoden, Anwendung in der Arbeit mit alten Menschen. Paderborn: Junfermann.

Pinter, G. (2001). Psychodrama training: A way to become a psychotherapist in Hungary. In P. Fontaine (Ed.), Psychodrama training: A European view (2nd ed.). Leuven: FEPTO Publications.

Rauch, S. L., van der Kolk, B. A., Fisler, R. E., et al. (1996). A symptom provocation study of posttraumatic stress disorder using positron emission tomography and script-driven imagery. Archives of General Psychiatry, 53(5), 380-387.

Rawlinson, J. W. (2000). Does psychodrama work? A review of the literature. British Journal of Psychodrama and Sociometry, 15, 67-101.

Reamer, F. J. (1992). The place of empiricism in social work. Journal of Social Work Education, 28, 260-269.

Renjilian, D. A., Perri, M. G., Nezu, A. M., McKelvey, W. F., Shermer, R. L., \& Anton, S. D. (2001). Individual versus group therapy for obesity. Journal of Consulting and Clinical Psychology, 69, 717-721.

Renouvier, P. (1958). The group psychotherapy movement: J.L. Moreno, its pioneer and founder. Psychodrama and Group Psychotherapy Monographs, No. 33. Beacon, NY: Beacon House.

Rezaeian, M. P., Mazumdar, D. P., \& Sen, A. K. (1997). The effectiveness of psychodrama in changing the attitudes among depressed patients. Journal of Personality and Clinical Studies. 
Roselló, J., Bernal, G., \& Rivera-Medina, C. (2008). Individual and group CBT and IPT for Puerto Rican adolescents with depressive symptoms. Cultural Diversity and Ethnic Minority Psychology, 14, 234-245.

Ridge, R. M. (2010). A literature review of psychodrama. Journal of Group Psychotherapy, Psychodrama, and Sociometry. Originally published in Ridge, R. M. (2007). The body alchemy of psychodrama: A phenomenologically-based qualitative evaluation of a training manual for trainers and practitioners of psychodrama and group psychotherapy. Union Institute and University, ProQuest Dissertations Publishing. Retrieved from: http://asgpp.org/pdf/Ridge\%20Journal. pdf.

Sackett, D. L., Rosenberg, W. M. C., Gray, J. A. M., Haynes, R. B., \& Richardson, W. S. (1996). Evidence-based medicine: What it is and what it isn't. British Medical Journal, 312(7023), 71-72.

Schmidt, B. (1978). Selbsterfahrung im Psychodrama als methode der Sozialtherapie fur studenten. Unpublished doctoral dissertation, University of Wurzburg.

Schnabel, K., \& Reif, J. (2016). Ways to evaluate psychodramatic training. In C. Stadler, M. Wieser, \& K. Kirk (Eds.), Psychodrama: Empirical research and science (Vol. 2, pp. 289-296). Wiesbaden: Springer.

Schramski, T. G., Feldman, C. A., Harvey, D. R., \& Holiman, M. A. (1984). A comparative evaluation of group treatment in an adult correctional facility. Journal of Group Psychotherapy, Psychodrama, \& Sociometry, 36, 133-147.

Shulman, L. (2016). Shifting the social work practice paradigm: The contribution of the Interactional Model. Journal of Social Work Education, 52(sup1), S16-S27.

Schwartze, D., Barkowski, S., Burlingame, G. M., Strauss, B., \& Rosendahl, J. (2016). Efficacy of group psychotherapy for obsessive-compulsive disorder: A meta-analysis of randomized controlled trials. Journal of Obsessive-Compulsive and Related Disorders, 10, 49-61.

Schwartze, D., Barkowski, S., Strauss, B., Burlingame, G. M., Barth, J., \& Rosendahl, J. (2017). Efficacy of group psychotherapy for panic disorder: Meta-analysis of randomized, controlled trials. Group Dynamics: Theory, Research, and Practice, 21(2), 77.

Schwartze, D., Barkowski, S., Strauss, B., Knaevelsrud, C., \& Rosendahl, J. (2019). Efficacy of group psychotherapy for posttraumatic stress disorder: Systematic review and meta-analysis of randomized controlled trials. Psychotherapy Research, 29(4), 415-431.

Schwinger, T. (2014). Die Rolle des Psychodramas in der Sozialarbeit. Zeitschrift für Psychodrama und Soziometrie, 13(1), 257-273.

Sharma, N. (2017). Effect of psychodrama therapy on depression and anxiety of Juvenile Delinquents. International Journal of Indian Psychology, 5(1), 38-47.

Sharp, D. M., Power, K. G., \& Swanson, V. (2004). A comparison of the efficacy and acceptability of group versus individual cognitive behaviour therapy in the treatment of panic disorder and agoraphobia in primary care. Clinical Psychology and Psychotherapy, 11, 73-82.

Shaw, I. G. R., \& Holland, S. (2014). Doing qualitative research in social work. London: Sage.

Shim, J. S. (2002). Psychodrama in improving the effects of interpersonal factors and treatment (Unpublished master's thesis). Seoul, Republic of Korea: Korea University.

Shlonsky, A., \& Gibbs, L. (2004). Will the real evidence-based practice please stand up? Teaching the process of evidence-based practice to the helping professions. Brief Treatment and Crisis Intervention, 4(2), 137-153.

Sloan, D. M., Feinstein, B., Gallagher, M. W., Beck, J. G., \& Keane, T. M. (2013). Efficacy of group treatment for posttraumatic stress disorder: A meta-analysis. Psychological Trauma: Theory, Research, Practice, and Policy, 5, 176-183.

Smith, M. L., Glass, G. V., \& Miller, T. I. (1980). The benefits of psychotherapy. Baltimore, MD: John Hopkins University Press.

Smokowsky, P., \& Bacallao, M. (2009). Entre Dos Mundos/between two worlds youth violence prevention: Comparing psychodramatic and support group delivery formats. Small Group Research, 40(1), 3-27.

Somov, P. G. (2008). A psychodrama group for substance use relapse prevention training. The Arts in Psychotherapy, 35(2), 151-161. 
Sproesser, E., Viana, M. A., Quagliato, E., \& de Souza, E. (2010). The effect of psychotherapy in patients with PD: A controlled study. Parkinsonism \& Related Disorders, 16(4), 298-300.

Souilm, N. M., \& Ali, S. A. (2017). Effect of psychodrama on the severity of symptoms in depressed patients. American Journal of Nursing Research, 5(5), 158-164.

Tabib, S. L. (2017). Effective psychodrama supervision a grounded theory study on senior supervisors' perspectives (Doctoral dissertation, Lesley University). Expressive Therapies Dissertations. 4. https://digitalcommons.lesley.edu/expressive_dissertations/4.

Tarashoeva, G., Marinova-Djambazova, P., \& Kojuharov, H. (2017). Effectiveness of psychodrama therapy in patients with panic disorders-Final results. International Journal of Psychotherapy, $21,55-66$.

Terry, R. (2000). Recent advances in measurement theory and the use of sociometric techniques. New Directions for Child and Adolescent Development, 88, 27-53.

Testoni, I., Bonelli, B., Biancalani, G., Zuliani, L., \& Nava, F. A. (2020). Psychodrama in attenuated custody prison-based treatment of substance dependence: The promotion of changes in wellbeing (p. 101650). Spontaneity: Perceived Self-Efficacy, and Alexithymia. The Arts in Psychotherapy.

Testoni, I., Cecchini, C., Zulian, M., Guglielmin, M. S., Ronconi, L., Kirk, K., et al. (2018). Psychodrama in therapeutic communities for drug addiction: A study of four cases investigated using idiographic change process analysis. The Arts in Psychotherapy, 61, 10-20.

Terzioğlu, C., \& Özkan, B. (2017). Psychodrama and the emotional state of women dealing with infertility. Sex Disability, 36, 87-99.

Treadwell, T. (2020). Integrating CBT with experiential theory and practice: A group therapy workbook. New York: Taylor \& Francis.

Treadwell, T., Collins, L., \& Stein, S. (1992). The Moreno social atom test-Revised (MSAT-R): A sociometric instrument measuring interpersonal networks. Journal of Group Psychotherapy, Psychodrama \& Sociometry, 45(3), 122-124.

Treadwell, T., Kumar, V., Stein, S., \& Prosnick, K. (1997). Sociometry: Tools for research and practice. The Journal for Specialists in Group Work, 22(1), 52-65.

Tubaro, P., Ryan, L., \& D' angelo, A. (2016). The visual sociogram in qualitative and mixed-methods research. Sociological Research Online, 21(2), 180-197.

van de Kamp, M. M., Scheffers, M., Hatzmann, J., Emck, C., Cuijpers, P., \& Beek, P. J. (2019). Bodyand movement-oriented interventions for posttraumatic stress disorder: A systematic review and meta-analysis. Journal of Traumatic Stress, 32(6), 967-976.

van der Kolk, B. A. (2014). The body keeps the score: Brain, mind, and body in the healing of trauma. New York: Viking Press.

Veiga, S., Bertão, A., \& Franco, V. (2015). Sociodrama in the training of social educators: An exploratory research. The Journal of Psychodrama, Sociometry, and Group Psychotherapy, 63(1), 47-64.

Waber, B. N., Olguin, D., Kim, T., Mohan, A., Ara, K., \& Pentland, A. (2007). Organizational engineering using sociometric badges. Social Science Research Network, 1073342.

Wampold, B. E. (2005). Establishing specificity in psychotherapy scientifically: Design and evidence issues. Clinical Psychology: Science and Practice, 12(2), 194-197.

Wampold, B. E. (2012). Humanism as a common factor in psychotherapy. Psychotherapy, 49(4), 445.

Wang, Q., Ding, F., Chen, D., Zhang, X., Shen, K., Fan, Y., \& Li, L. (2020). Intervention effect of psychodrama on depression and anxiety: A meta-analysis based on Chinese samples. The Arts in Psychotherapy, 101661.

White, E. W., Rosenblatt, E., Love, A., \& Little, D. (1982). Psychodrama and life skills: A treatment alternative in child abuse. Unpublished manuscript, Toronto Center for Psychodrama and Sociometry.

Wieser, M. (2007). Studies on treatment effects of psychodrama psychotherapy. In C. Baim, Clark, J. Burmeister, \& M. Maciel (Eds.), Psychodrama: Advances in theory and practice (pp. 271-292). New York: Routledge/Taylor \& Francis Group. 
Wike, T. L., Bledsoe, S. E., Manuel, J. I., Despard, M., Johnson, L. V., Bellamy, J. L., et al. (2014). Evidence-based practice in social work: Challenges and opportunities for clinicians and organizations. Clinical Social Work Journal, 42(2), 161-170.

Witkin, S. L. (1991). Empirical clinical practice: A critical analysis. Social Work, 36(2), 158-163.

Witkin, S. (2017). Transforming social work: Social constructionist reflections on contemporary and enduring issues. London: Palgrave.

Wood, D., Del Nuovo, A., Bucky, S. F., Schein, S., \& Michalik, M. (1979). Psychodrama with an alcohol abuser population. Group Psychotherapy, Psychodrama, \& Sociometry, 32, 75-88.

Yalom, I. D. (2002). The gift of therapy: An open letter to a new generation of therapists and their patients. New York: HarperCollins Publishers.

Yalom, I. D., \& Leszcz, M. (2005). The theory and practice of group psychotherapy (5th ed.). New York, NY: Basic Books.

Open Access This chapter is licensed under the terms of the Creative Commons Attribution 4.0 International License (http://creativecommons.org/licenses/by/4.0/), which permits use, sharing, adaptation, distribution and reproduction in any medium or format, as long as you give appropriate credit to the original author(s) and the source, provide a link to the Creative Commons license and indicate if changes were made.

The images or other third party material in this chapter are included in the chapter's Creative Commons license, unless indicated otherwise in a credit line to the material. If material is not included in the chapter's Creative Commons license and your intended use is not permitted by statutory regulation or exceeds the permitted use, you will need to obtain permission directly from the copyright holder. 